\title{
Angiotensin II type 1 receptor blockers increase tolerance of cells to copper and cisplatin
}

\author{
Pieter Spincemaille ${ }^{1,+}$, Gursimran Chandhok ${ }^{2,+}$, Andree Zibert ${ }^{2}$, Hartmut Schmidt ${ }^{2}$, Jef Verbeek ${ }^{3}$, Patrick \\ Chaltin ${ }^{4,5}$, Bruno P.A. Cammue ${ }^{1,6, \#, *}$, David Cassiman ${ }^{3}$, Karin Thevissen ${ }^{1, \#, *}$ \\ ${ }^{1}$ Centre of Microbial and Plant Genetics (CMPG), KU Leuven, Kasteelpark Arenberg 20, 3001 Heverlee, Belgium. \\ ${ }^{2}$ Clinic for Transplantation Medicine, Münster University Hospital, Albert-Schweitzer-Campus 1, Building A14, D-48149 Münster, \\ Germany. \\ ${ }^{3}$ Department of Hepatology and Metabolic Center, University Hospital Gasthuisberg, Herestraat 49, 3000 Leuven, Belgium. \\ ${ }^{4}$ CISTIM Leuven vzw, Bio-Incubator 2, Wetenschapspark Arenberg, Gaston Geenslaan 2, 3001 Heverlee, Belgium. \\ ${ }^{5}$ Centre for Drug Design and Discovery (CD3), KU Leuven R\&D, Waaistraat 6, Box 5105, 3000 Leuven. \\ ${ }^{6}$ Department of Plant Systems Biology, VIB, Technologiepark 927, 9052, Ghent, Belgium. \\ + Both authors contributed equally to this work. \\ \# Authors coordinated equally. \\ * Corresponding Authors: Bruno P.A. Cammue, Centre for Microbial and Plant Genetics, KU Leuven, Kasteelpark Arenberg 20; 3001 \\ Heverlee, Belgium; Tel: +32 1632 9682; Fax: +32 1632 1966; E-mail: bruno.cammue@biw.kuleuven.be \\ Karin Thevissen, Centre for Microbial and Plant Genetics, KU Leuven, Kasteelpark Arenberg 20; 3001 Heverlee, Belgium; Tel: +32 \\ 1632 9688; Fax: +32 1632 1966; E-mail: karin.thevissen@biw.kuleuven.be
}

\begin{abstract}
The human pathology Wilson disease (WD) is characterized by toxic copper $(\mathrm{Cu})$ accumulation in brain and liver, resulting in, among other indications, mitochondrial dysfunction and apoptosis of hepatocytes. In an effort to identify novel compounds that can alleviate $\mathrm{Cu}$-induced toxicity, we screened the Pharmakon 1600 repositioning library using a $\mathrm{Cu}$-toxicity yeast screen. We identified 2 members of the drug class of Angiotensin II Type 1 receptor blockers (ARBs) that could increase yeast tolerance to $\mathrm{Cu}$, namely Candesartan and Losartan. Subsequently, we show that specific ARBs can increase yeast tolerance to $\mathrm{Cu}$ and/or the chemotherapeutic agent cisplatin (Cp). The latter also induces mitochondrial dysfunction and apoptosis in mammalian cells. We further demonstrate that specific ARBs can prevent the prevalence of $\mathrm{Cu}$-induced apoptotic markers in yeast, with Candesartan Cilexetil being the ARB which demonstrated most pronounced reduction of apoptosis-related markers. Next, we tested the sensitivity of a selection of yeast knockout mutants affected in detoxification of reactive oxygen species (ROS) and $\mathrm{Cu}$ for Candesartan Cilexetil rescue in presence of $\mathrm{Cu}$. These data indicate that Candesartan Cilexetil increases yeast tolerance to $\mathrm{Cu}$ irrespectively of major ROS-detoxifying proteins. Finally, we show that specific ARBs can increase mammalian cell tolerance to $\mathrm{Cu}$, as well as decrease the prevalence of $\mathrm{Cu}$-induced apoptotic markers. All the above point to the potential of ARBs in preventing $\mathrm{Cu}$-induced toxicity in yeast and mammalian cells.
\end{abstract}

doi: $10.15698 /$ mic2014.11.175 Received originally: 23.05.2014; in revised form: 26.09.2014, Accepted 08.10.2014, Published 24.10.2014.

Keywords: sartans, copper, cisplatin, drug repositioning.
Abbreviations:
aSMase - acid sphingomyelinase, $C p$ - cisplatin,
Cu- copper,
ROS - reactive oxygen species,
SL - sphingolipid.

\section{INTRODUCTION}

The human pathology Wilson disease (WD) is characterized by excess copper $(\mathrm{Cu})$ accumulation in the brain and liver, leading to liver failure or cirrhosis and neurodegeneration [1-3]. Cu toxicity is directly related to mitochondrial dysfunction and apoptosis in mammalian cells [4] as it induces oxidative stress $[5,6]$ and crosslinking of mitochondrial membrane proteins causing the membrane to contract [7] In addition, $\mathrm{Cu}$ causes a malfunction of complex IV of the respiratory chain [8] and increases acid sphingomyelinase (aSMase) activity [9], the latter leading to an increased production of the apoptosis inducer ceramide [10]. Furthermore, the chemotherapeutic agent cisplatin $(C p)$ also induces mitochondrial dysfunction in mammalian cells by 
decreasing respiration [11], causing mitochondrial membrane depolarization [12], inducing the production of reactive oxygen species (ROS) [13], and affecting mitochondrial structure and function [14]. In addition, mitochondria generate ROS upon exposure to $\mathrm{Cp}$ in both yeast and mammalians cells [13], indicating that $\mathrm{Cp}$-induced toxicity shows similarity between yeast and mammalian cells. In yeast, there are several contradictory reports on Cu-induced toxicity and mitochondrial dysfunction. Some reports have demonstrated the negative impact of non-lethal $\mathrm{Cu}$ doses on the mitochondrial proteome and function in yeast, resulting in decreased ATP production and activation of the oxidative stress response [15], and mitochondrial abnormalities [16]. In contrast, Cu-treatment of yeast has also been reported to increase the mitochondrial $\mathrm{Cu}$ content without causing respiratory deficits [17]. Apart from direct effects of $\mathrm{Cu}$ on mitochondrial function, Cu toxicity in $S$. cerevisiae has been linked to perturbations in sphingolipid (SL) homeostasis [18], which are crucial membrane components with regard to apoptosis [19] and mitochondrial function [20, 21]. In contrast, Lee and coworkers did not show any alterations in a subset of SL species in response to $\mathrm{Cu}$ treatment [22]. Hence, the question whether $\mathrm{Cu}$ indeed results in mitochondrial dysfunction in yeast remains under debate. Nonetheless, by using a Cu-induced toxicity screen in yeast, we previously identified an Arabidopsis thaliana-derived decapeptide termed OSIP108 [23] as a peptide that can increase yeast tolerance to $\mathrm{Cu}$. More specifically, we showed that OSIP108 prevents Cu-induced apoptosis in yeast and human cells, and preserves mitochondrial ultrastructure in human cells [18]. Furthermore, we were able to link these observations to perturbations in SL homeostasis by OSIP108 [18]. In addition, we translated these data toward a novel zebrafish model for Cu toxicity and showed that OSIP108 injections into zebrafish larvae prevented $\mathrm{Cu}$-induced hepatotoxicity and decreased oxidative stress levels [24]. Thus, despite the contradictory reports in literature, by using our Cu-toxicity yeast screen, we identified OSIP108, and were able to translate our yeast data to higher eukaryotic cell models, as well as to an in vivo model for $\mathrm{Cu}$-intoxication, thereby validating our $\mathrm{Cu}$ -

TABLE 1. Effect of the selected ARBs on $\mathrm{Cu}$ and $\mathrm{Cp}$-induced toxicity in yeast. ' $t$ ' and ' - ' denotes effective and ineffective, respectively.

\begin{tabular}{lccc} 
& \multicolumn{2}{c}{ Toxicity } \\
& ARB & Cu & Cp \\
\hline Candesartan & - & + \\
\hline Candesartan Cilexetil & + & + \\
\hline Eprosartan & - & - \\
\hline Irbesartan & - & + \\
\hline Losartan & + & + \\
\hline Olmesartan & - & - \\
\hline Olmesartan Medoxomil & + & + \\
\hline Telmisartan & - & - \\
\hline Trityl Candesartan Cilexetil & - & - \\
\hline Valsartan & + & - \\
\hline
\end{tabular}

toxicity screen in yeast in the context of apoptosis and mitochondrial dysfunction.

In an effort to identify small molecules that can alleviate $\mathrm{Cu}$-induced toxicity in yeast, we screened the Pharmakon 1600 repositioning library consisting of 1600 drugs, which are marketed or have been tested in clinical trials. Drug repositioning is referred to as the identification and development of new uses of existing or abandoned drugs. It possesses several advantages over de novo drug discovery such as known safety and pharmacokinetic profiles, as well as knowledge of manufacturing and toxicology of the compounds investigated $[25,26]$. Current fields of interest for application of such repurposing strategy include the identification of novel antibiotics [27], the increase of effectiveness of existing antimycotics by potentiation [28], but also novel treatments for orphan diseases [29]. The Pharmakon library was screened in our Cu-based yeasttoxicity screen [18]. Repurposed compounds that scored positive in this $\mathrm{Cu}$-based yeast toxicity screen were further tested for their potential to increase yeast tolerance to $C p$, another inducer of mitochondrial dysfunction. Subsequently, we translated these data to a mammalian cell setting. All our data point to the protective effect of ARBs against Cu-induced toxicity.

\section{RESULTS}

Screening for compounds that can increase yeast tolerance to $\mathrm{Cu}$

The Pharmakon 1600 repositioning library was screened for agents that can increase yeast tolerance to $\mathrm{Cu}$ as described previously [18]. Briefly, WT yeast was inoculated in solid growth medium containing a lethal $\mathrm{Cu}$ concentration $(100 \mu \mathrm{M})$ and the viability indicator dye MTT $(0.1 \mathrm{mg} / \mathrm{mL})$. All 1600 compounds ( $10 \mathrm{mM}$ in DMSO) were spotted ( $5 \mu \mathrm{L}$ ) onto the solid agar. Following $24 \mathrm{~h}$ of incubation, the plates were checked for development of purple halos around the spotted compounds, resulting from the conversion of the viability dye MTT and thus indicative for viable cells. Given that $\mathrm{Cu}$ chelation or sequestration is one of the main cellular $\mathrm{Cu}$ detoxification mechanisms $[30,31]$, we identified several agents with known chelating activity such as Deferoxamine Mesylate [32] and Oxyquinoline Sulfate [33]. Hence, such agents were omitted to exclude aspecific $\mathrm{Cu}$ chelation. This resulted in the identification of seven compounds (data not shown) that are not known to chelate $\mathrm{Cu}$ and can increase tolerance of yeast cells to $\mathrm{Cu}$. Among them were two members of the drug class of Angiotensin II Type 1 receptor blockers (ARBs) [34], namely Candesartan and Losartan.

Given the fact that several studies have documented beneficial effects of ARBs, such as Candesartan and Losartan, on human pathologies linked to mitochondrial dysfunction and apoptosis, such as diabetes, Alzheimer disease and aging [35-42], we selected the drug class of ARBs for further characterization of their activity using the model yeast $S$. cerevisiae. 


\section{Angiotensin II Type 1 receptor blockers increase yeast survival in presence of toxic $\mathrm{Cu}$ and $\mathrm{Cp}$}

We investigated the effect of a selection of commercially available ARBs, namely Eprosartan, Irbesartan, Losartan, Olmesartan, Olmesartan Medoxomil, Telmisartan, Trityl Candesartan Cilexetil and Valsartan (Table 1), on yeast survival in presence of toxic $\mathrm{Cu}$ and $\mathrm{Cp}$. The prototype of the class of ARBs is Losartan [43], from which additional ARBs were derived based on modification of its chemical structure, such as Candesartan, Valsartan and Olmesartan [34]. We found that incubation of yeast cells with $2 \mathrm{mM} \mathrm{Cu}$ resulted in approx. 23\% yeast survival, whereas treatment of $\mathrm{Cu}$-stressed yeast with either $100 \mu \mathrm{M}$ Candesartan Cilexetil, Losartan, Olmesartan Medoxomil or Valsartan significantly increased yeast survival. No significant increase in survival of Cu-stressed yeast cells was observed upon incubation with $100 \mu \mathrm{M}$ Candesartan, Eprosartan, Irbesartan, Olmesartan, Telmisartan or Trityl Candesartan (Fig. 1 a). These results indicate that particular ARBs can increase yeast tolerance to excess $\mathrm{Cu}$. Note that while Candesartan was identified during our screen, it failed to significantly increase yeast survival in presence of $\mathrm{Cu}$, as determined by plating colony-forming units (CFU). It is expected that the CFU-based assay is more stringent, resulting in the selection of the most potent ARBs with regard to increasing $\mathrm{Cu}$ tolerance.

We further evaluated the effect of the ARBs against $\mathrm{Cp}$ induced toxicity in yeast. Incubation of yeast cells with 250 $\mu \mathrm{M} C p$ decreased yeast survival to about $5 \%$ whereas cotreatment with either $100 \mu \mathrm{M}$ Candesartan, Candesartan Cilexetil, Irbesartan, Losartan or Olmesartan Medoxomil significantly increased survival as compared to control treatment. No significant effect on survival of Cp-stressed yeast cells was observed with treatment of $100 \mu \mathrm{M}$ Eprosartan, Olmesartan, Telmisartan, Trityl Candesartan Cilexetil or Valsartan (Fig. 1 b). These data indicate that particular ARBs can prevent $\mathrm{Cp}$-induced toxicity in yeast.

Interestingly, in our experiments only Candesartan Cilexetil, Losartan and Olmesartan Medoxomil increased yeast tolerance to both $\mathrm{Cu}$ and $\mathrm{Cp}$ (Table 1), suggesting that these three ARBs are the most interesting candidates. Structural classification of ARBs is based on the cycle replacing the imidazole ring in Losartan: in Candesartan Cilexetil, this imidazole group is replaced by a benzimidazole group, while in Olmesartan Cilexetil it is a imidazole derivate [34]. Since these three ARBs significantly increased yeast tolerance to both $\mathrm{Cu}$ and $\mathrm{Cp}$ (Fig. $1 \mathrm{a}$, b) and Candesartan Cilexetil is the most structurally different from Losartan (Fig. $1 \mathrm{c}$ ), we selected the prototype ARB Losartan and Candesartan Cilexetil for further characterization. For a more detailed description on the chemical structure of ARBs the reader is referred to $[34,44]$.

In order to gain insight into the efficacy of Candesartan Cilexetil and Losartan against $\mathrm{Cu}$ or $\mathrm{Cp}$-induced toxicity in $\mathrm{S}$. cerevisiae, we evaluated different doses $(25 \mu \mathrm{M}-100 \mu \mathrm{M})$ of either ARB on yeast survival in presence of toxic $\mathrm{Cu}(2$ $\mathrm{mM})$ or $\mathrm{Cp}(250 \mu \mathrm{M})$. We found that all tested doses of
Candesartan Cilexetil and Losartan significantly increased yeast tolerance to $\mathrm{Cu}$ (Fig. $1 \mathrm{~d}$ ). Conversely, we observed that only $100 \mu \mathrm{M}$ Candesartan Cilexetil and $100 \mu \mathrm{M}$ Losartan significantly increased yeast survival in presence of $\mathrm{Cp}$ (Fig. 1 e). These data indicate that ARBs can protect yeast against $\mathrm{Cu}$-induced toxicity in a broad concentration range, while only high doses of ARBs confer protection against $\mathrm{Cp}$ induced toxicity.

In order to exclude a general stress-protectant effect of ARBs, we also evaluated the effect of ARBs against a panel of noxious insults such as tunicamycin, the anti-convulsant valproic acid, acetic acid and CCCP. To this end we monitored yeast growth in presence of either insult in absence (control) or presence of $100 \mu \mathrm{M}$ Candesartan Cilexetil and/or Losartan. In contrast to the effect of ARBs on yeast growth in presence of $\mathrm{Cp}$, we did not observe an effect of the tested ARBs against either insult (Supplemental Fig 1 ae). These results suggest that ARBs cannot rescue general yeast growth defects induced by toxic triggers including tunicamycin, valproic acid, acetic acid or CCCP and hence, that the ARB-protecting action against noxious insults seems toxin-specific.

\section{ARBs affect $\mathrm{Cu}$-induced apoptotic markers in yeast}

As excess $\mathrm{Cu}$ is known to induce apoptosis [18, 45], we investigated the effect of Losartan and Candesartan Cilexetil on Cu-induced ROS production and DNA fragmentation, both markers of apoptosis [46]. In line with our previous results [18], we observed that $2 \mathrm{mM} \mathrm{Cu}$ significantly increased the amount of cells stained positive with dihydroethidium (DHE) (Fig. 2 a), indicating the induction of ROS and more specifically superoxide by $\mathrm{Cu}$. Co-incubation with $100 \mu \mathrm{M}$ Candesartan Cilexetil significantly decreased the levels of DHE positive cells in presence of $2 \mathrm{mM} \mathrm{Cu}$ (Fig. 2 a). By using the Terminal dUTP Nick End Labeling (TUNEL) assay, we observed that $2 \mathrm{mM} \mathrm{Cu}$ significantly induced DNA fragmentation in yeast, while treatment with either $100 \mu \mathrm{M}$ Candesartan Cilexetil or Losartan significantly decreased the amount of $\mathrm{Cu}$-induced TUNEL positive cells (Fig $2 \mathrm{~b})$. These data suggest that specific ARBs may differentially affect $\mathrm{Cu}$-induced markers of apoptosis, and that Candesartan Cilexetil is the most potent in decreasing these markers.

In order to increase our understanding of $\mathrm{Cu}$-induced cell death in yeast, which occurs presumably via apoptosis $[18,45]$, we evaluated the Cu-tolerance and the rescuing effect of ARBs of wild type yeast (BY4741) and a selection of yeast mutants defective in components of the apoptotic machinery such as $\Delta a i f 1, \Delta$ nuc1 or $\Delta y c a 1$ mutants. To this end, we spotted serial dilutions of these yeast cultures onto Cu-containing (1.25 mM - $1.5 \mathrm{mM})$ solid growth media in the presence of control (0.5\% DMSO) or Candesartan Cilexetil $(100 \mu \mathrm{M})$. This selection of mutants was also recently tested to characterize cell death induced by Mentha piperita essential oil in S. cerevisiae [47]. Aif1p and Nuc1p are mitochondrial cell death effectors that translocate to the nucleus in response to apoptotic stimuli such as hydro- 
a

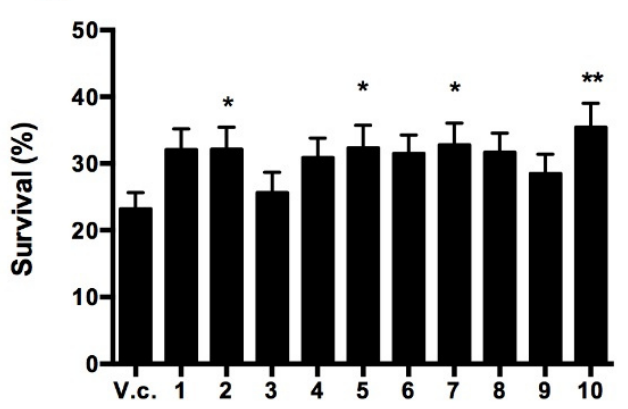

b

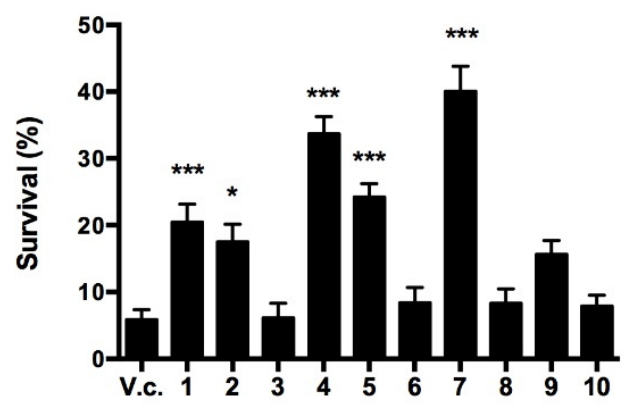

C

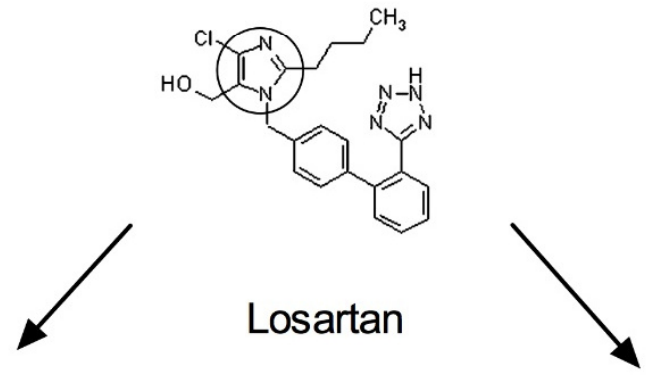

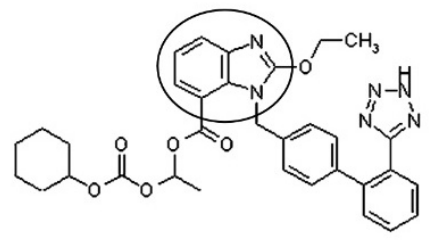

Candesartan Cilexetil

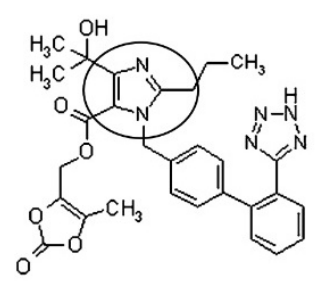

Olmesartan Medoxomil d

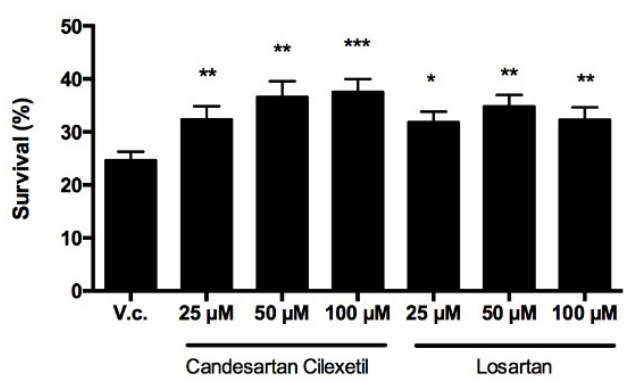

e

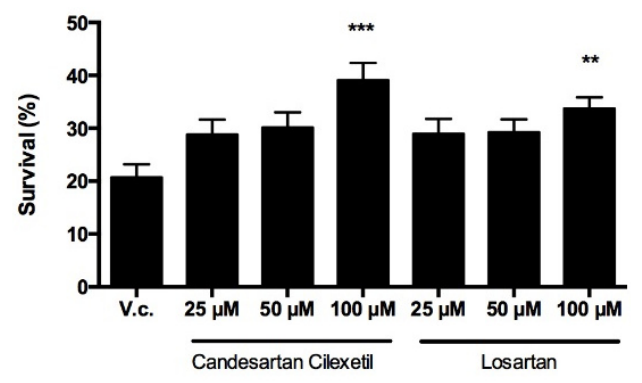

FIGURE 1: ARBs prevent $\mathrm{Cu}$ and $\mathrm{Cp}$-induced killing of yeast cells. Yeast cells were incubated with $2 \mathrm{mM}$ Cu for $4 \mathrm{~h}$ (a, d) or $250 \mu \mathrm{M}$ Cp for $16 \mathrm{~h} \mathrm{(b,} \mathrm{e)} \mathrm{in} \mathrm{presence} \mathrm{of} \mathrm{vehicle} \mathrm{control} \mathrm{(V.c,} \mathrm{2.5 \%} \mathrm{DMSO)} \mathrm{or} 100 \mu \mathrm{M}$ Candesartan (1), Candesartan Cilexetil (2), Eprosartan (3), Irbesartan (4), Losartan (5), Olmesartan (6), Olmesartan Medoxomil (7), Telmisartan (8), Trityl Candesartan Cilexetil (9) or Valsartan (10). (c) Chemical structure of the prototype Losartan, of which Candesartan Cilexetil and Olmesartan Medoxomil are derived. The benzimidazole group in Candesartan Cilexetil and the imidazole ring in Losartan and Olmesartan Medoxomil are circled. Taken and adapted from [44]. Yeast survival in presence of different doses of Candesartan Cilexetil or Losartan upon treatment with $2 \mathrm{mM}$ Cu (d) or $250 \mu \mathrm{M}$ Cp (e). Survival was calculated by determining CFU/ml as compared to untreated control cells (no $\mathrm{Cu}$ or $\mathrm{Cp}$ ). Experiment performed in quadruplicate, with at least two biological repeats. ( ${ }^{*} \mathrm{P}<0.05 ;{ }^{* *} \mathrm{P}<0.01 ;{ }^{* * *} \mathrm{P}<0.001$; ANOVA test using Tukey correction). 
gen peroxide $[48,49]$. Yca1p is the yeast metacaspase and is implicated as a crucial cell death effector during $\mathrm{H}_{2} \mathrm{O}_{2}$ - or acetic acid-induced apoptosis [50,51]. We observed that the $\Delta y c a 1$ mutant did not display altered susceptibility to toxic $\mathrm{Cu}$ as compared to wild type yeast, which is in line with literature $[18,45,52]$, nor did $\Delta a i f 1$ or $\Delta$ nuc1 mutants (Supplemental Fig. 2, middle and right panel). Candesartan Cilexetil supplementation, however, increased viability of all yeast mutants (Supplemental Fig. 2, middle and right panels). Taken together, these data suggest that $\mathrm{Cu}$ induced apoptosis in yeast is independent of Aif1p, Nuc1p and Yca1p, and that Candesartan Cilexetil increases yeast tolerance to $\mathrm{Cu}$ independently of the latter three proteins.

Exogenous addition of the plant decapeptide OSIP108 does not affect the protective effect of Candesartan Cilexetil against $\mathrm{Cu}$-induced toxicity in yeast

As we previously identified the $A$. thaliana-derived decapeptide OSIP108 [23] as a potent rescuer from $\mathrm{Cu}$ toxicity of yeast and human cells [18], we evaluated whether OSIP108 can influence the effect of Candesartan Cilexetil on Cu-induced cell death in yeast. Thus, we investigated a putative synergy between Candesartan Cilexetil and OSIP108.

To this end, we first identified an OSIP108 dose that did not affect yeast Cu-tolerance, being $12.5 \mu \mathrm{M}$ or $25 \mu \mathrm{M}$ OSIP108 (Fig. 2 c). Subsequently, we found that these OSIP108 doses neither increased nor decreased the protective effect of Candesartan Cilexetil $(100 \mu \mathrm{M})$ against Cuinduced toxicity in yeast (Fig. $2 \mathrm{c}$ ), suggesting that the structurally unrelated OSIP108 and Candesartan Cilexetil affect yeast tolerance to $\mathrm{Cu}$ via distinct pathways.

\section{Candesartan Cilexetil increases yeast mutant tolerance to} $\mathrm{Cu}$

To get preliminary insights into the role of ROS during $\mathrm{Cu}$ induced toxicity in yeast, we evaluated the Cu tolerance of a panel of yeast deletion mutants defective in ROS detoxification ( $\Delta$ cta1, $\Delta c t t 1, \Delta \operatorname{grx} 5, \Delta \operatorname{sod} 1, \Delta \operatorname{sod} 2$ ), at least partly defective in cytoplasmic ROS production ( $\Delta y$ no1) or $\mathrm{Cu}$ sequestration $(\Delta c r s 5, \Delta c u p 2)$. The catalases Cta1p and Ctt1p detoxify the ROS $\mathrm{H}_{2} \mathrm{O}_{2}$ in the peroxisomes and cytosol, respectively $[53,54]$. During respiratory growth conditions Cta1p also resides in the mitochondria [54]. In addition, the superoxide dismutases Sod1 $p$ and Sod2p detoxify superoxide, thereby generating oxygen and $\mathrm{H}_{2} \mathrm{O}_{2}$, mainly in the cytosol and mitochondria, respectively $[55,56]$. Furthermore, we included yeast mutants defective in Grx5p, a mitochondrial glutathione-dependent oxidoreductase that plays a crucial role in defense against oxidative stress [57], and Yno1p, a NADPH oxidase in the endoplasmic reticulum that is responsible for extra-mitochondrial superoxide production [58]. In addition, given that $\mathrm{Cu}$ sequestration is one of the major $\mathrm{Cu}$-detoxification mechanisms, we included the Cu-binding metallothionein $\operatorname{Crs5p~[59]~and~the~Cu-~}$ binding transcription factor Cup2 $p$, which initiates transcription of the genes encoding the metallothioneins CUP11 and CUP1-2 [60, 61]. Serial dilutions of wild type (BY4741) and these mutants were spotted onto control (0 a

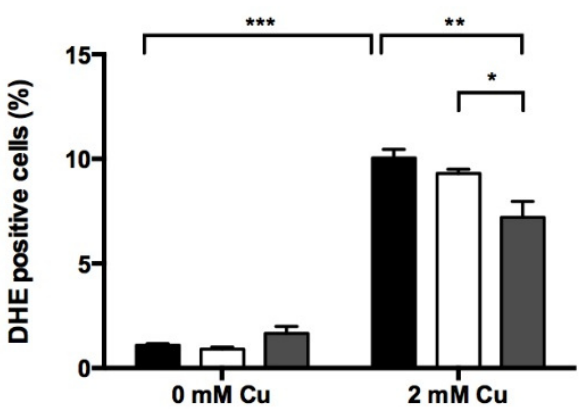

b

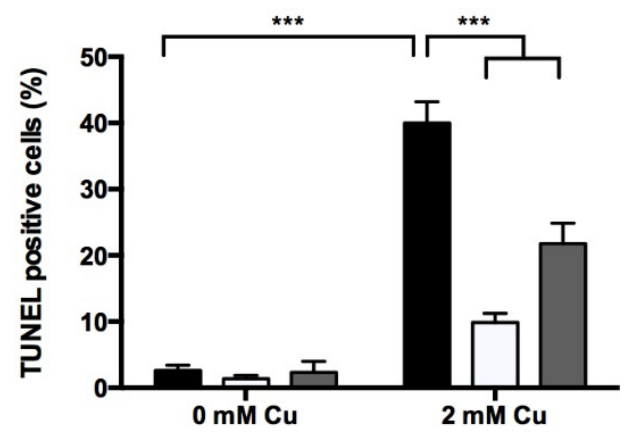

C

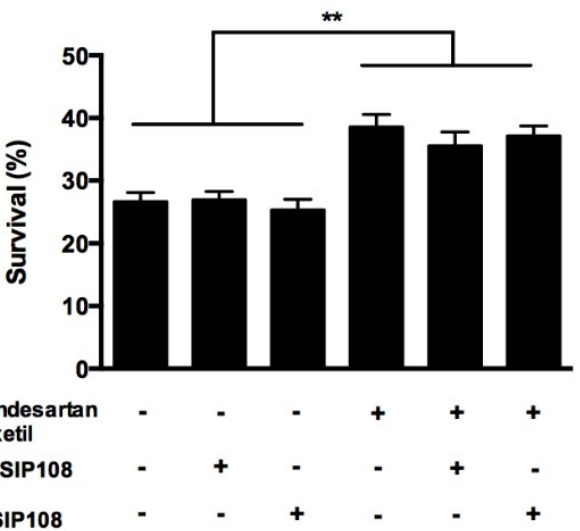

FIGURE: 2. ARBs reduce levels of $\mathrm{Cu}$ induced apoptotic markers in yeast. Yeast cells were incubated with $2 \mathrm{mM} \mathrm{Cu}$ for $4 \mathrm{~h}$ with control treatment (black bars), Losartan (white bars) or Candesartan Cilexetil (gray bars). Following treatment, cells were stained with DHE (a) or TUNEL assay (b) and subsequently analyzed by flow cytometry or counted manually after fluorescence microscopy, respectively. Three biological repeats were used. ( ${ }^{*} P<0.05$; $* * \mathrm{P}<0.01 ; * * * \mathrm{P}<0.001$; ANOVA test using Tukey correction). (c) OSIP108 does not affect the rescue effect of Candesartan Cilexetil. Yeast cells were incubated with $2 \mathrm{mM} \mathrm{Cu}$ for $4 \mathrm{~h}$ with control treatment, Candesartan Cilexetil $(100 \mu \mathrm{M})$ in absence (2\% DMSO) or presence of OSIP108 $(12.5 \mu \mathrm{M}-25 \mu \mathrm{M})$. Following incubation, cells were plated on YPD agar plates and survival was calculated as compared to $\mathrm{CFU} / \mathrm{ml}$ of cells receiving no $\mathrm{Cu}$. Experiments performed in quadruplicate with three biological repeats. ( ${ }^{*} \mathrm{P}<0.05$; ${ }^{* *} \mathrm{P}<0.01 ;{ }^{* * *} \mathrm{P}<0.001 ;$ ANOVA test using Tukey correction). 


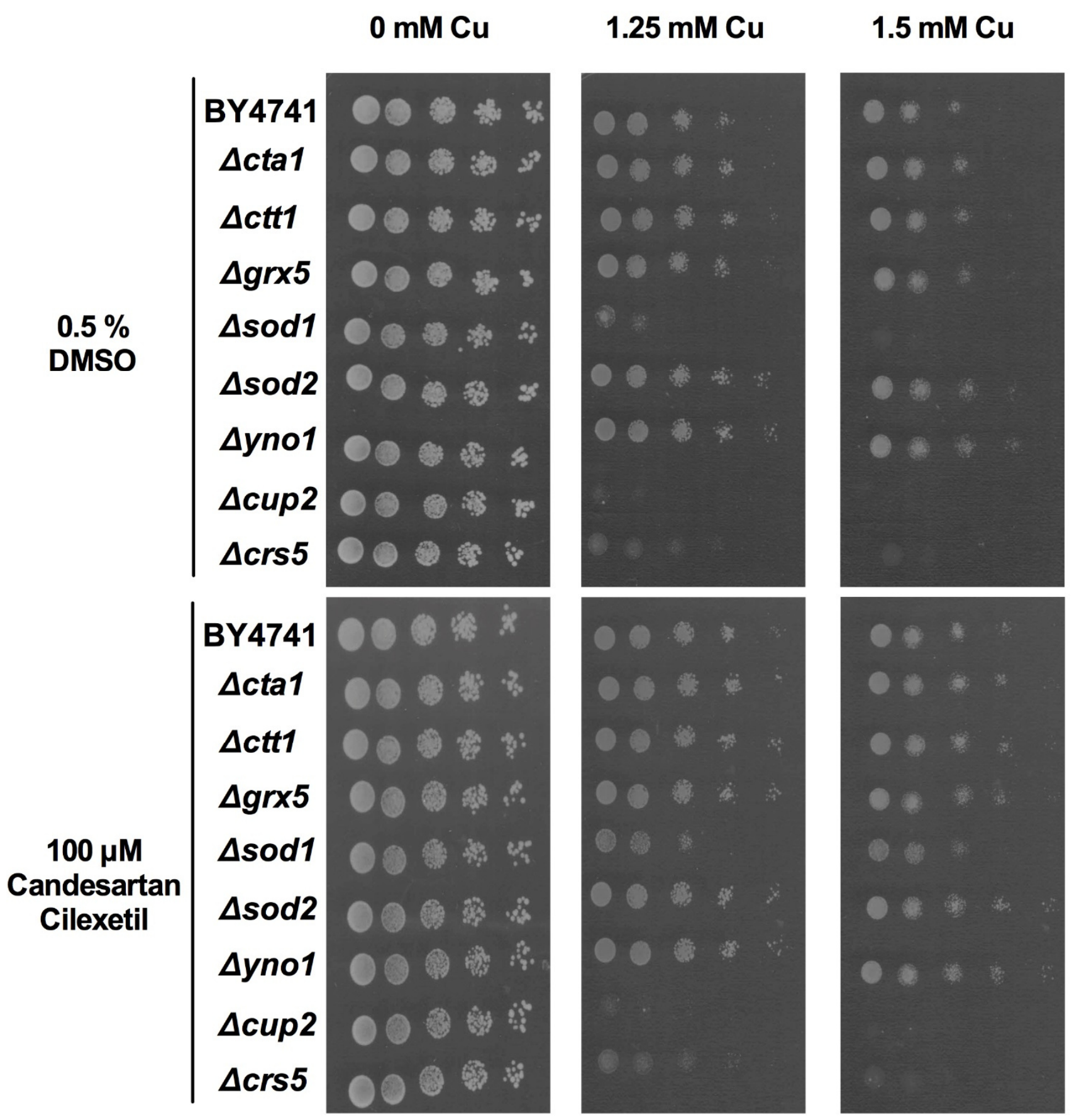

FIGURE 3: Effect of Candesartan Cilexetil on Cu tolerance of yeast mutants. Serial dilutions of wild type (WT), $\Delta c t a 1, \Delta c t t 1, \Delta g r x 5, \Delta s o d 1$, $\Delta$ sod2, $\Delta y n o 1, \Delta$ cup2 and $\Delta c r s 5$ were spotted onto control $(0 \mathrm{mM} \mathrm{Cu})$ or Cu-containing $(1.25 \mathrm{mM}-1.5 \mathrm{mM})$ solid SC media in presence of control (0.5\% DMSO; top panels) or $100 \mu \mathrm{M}$ Candesartan Cilexetil (bottom panels). Growth was evaluated following $48 \mathrm{~h}$ incubation at $30^{\circ} \mathrm{C}$. Data representative for two biological repeats.

$\mathrm{mM} \mathrm{Cu})$ or Cu-containing $(1.25 \mathrm{mM}-1.5 \mathrm{mM})$ solid growth media supplemented with either control (0.5\% DMSO) or Candesartan Cilexetil (100 $\mu \mathrm{M})$.

We found that while loss of Sod1p, Cup2p or Crs5p severely increased yeast sensitivity to $\mathrm{Cu}$, loss of Sod2p or Yno1p moderately increased yeast tolerance to $\mathrm{Cu}$ (Fig. 3, middle and right panels). Loss of Sod $2 p$ was already previously shown to increase yeast tolerance to copper nitrate
[62] while loss of Yno1p is documented to increase yeast tolerance to apoptotic stimuli [58]. In contrast, supplementation with Candesartan Cilexetil increased the $\mathrm{Cu}$ tolerance of all yeast mutants, except $\Delta c r s 5$ and $\Delta c u p 2$ mutants. Given the evident increased susceptibility to $\mathrm{Cu}$ of the latter two mutants, this suggests that both proteins are crucial in conferring $\mathrm{Cu}$ tolerance in yeast and their loss is detrimental for yeast viability in presence of $\mathrm{Cu}$ to an extent 
that Candesartan Cilexetil is unable to counteract this toxicity. However, additional experiments are required to determine whether Candesartan Cilexetil directly acts on metallothionein levels/activity. Surprisingly, given the increased and decreased susceptibility of $\Delta$ sod 1 and $\Delta y n o 1$ mutants to $\mathrm{Cu}$, respectively, this points to deleterious cytoplasmic, rather than mitochondrial, ROS production during $\mathrm{Cu}$-induced toxicity in yeast. However, this does not exclude mitochondrial ROS production upon $\mathrm{Cu}$ treatment in yeast. Note that $\mathrm{Cu}$ is an essential cofactor for Sod1p, and loss of this protein may trigger defective $\mathrm{Cu}$ storage. Taken together, further research is needed to pinpoint the cellular targets of Candesartan Cilexetil in the context of $\mathrm{Cu}$ toxicity in yeast.

\section{ARBs prevent $\mathrm{Cu}$-induced apoptosis in the human hepa- toma HepG2 cell line}

In an effort to translate our yeast data to a higher eukaryotic cell model, we investigated the effect of the ARBs Candesartan Cilexetil and Losartan on Cu-induced apoptosis in the human hepatoma HepG2 cell line. To this end we first evaluated HepG2 survival in absence of Cu upon incubation with Candesartan Cilexetil and Losartan. In initial experiments we titrated the Candesartan Cilexetil or Losartan dose to investigate a putative ARB-associated toxicity towards HepG2 cells, and observed that while doses higher than $25 \mu \mathrm{M}$ Candesartan Cilexetil induced killing of HepG2 cells, $100 \mu \mathrm{M}$ Losartan did not have an effect on cell viability (data not shown). Subsequently, we investigated the effect of $25 \mu \mathrm{M}$ Candesartan Cilexetil and $100 \mu \mathrm{M}$ Losartan on HepG2 cell viability in presence of different $\mathrm{Cu}$ concentrations. While ARB treatment in presence of $\mathrm{Cu}$ doses that decreased cell viability by less than $50 \%$ did not result in any significant effects (Fig. 4 a), we found that only $100 \mu \mathrm{M}$ Losartan significantly increased cell viability upon treatment with $1 \mathrm{mM}$ or $1.25 \mathrm{mM} \mathrm{Cu}$ (Fig. 4 a): HepG2 viability decreased to approx. $28 \%$ or $8 \%$ upon treatment with 1
$\mathrm{mM}$ or $1.25 \mathrm{mM} \mathrm{Cu}$, respectively, while coincubation with $100 \mu \mathrm{M}$ Losartan resulted in $46 \%$ or $26 \%$ viability respectively. Coincubation with $25 \mu \mathrm{M}$ Candesartan Cilexetil and $\mathrm{Cu}$ did not affect cell viability. These data suggest that particular ARBs confer protection against severe $\mathrm{Cu}$-induced cell death in mammalian cells.

Subsequently, similar as to our yeast experiments, we evaluated the effect of Candesartan Cilexetil and Losartan on Cu-induced apoptosis in HepG2 cells by FLUOS-labeled Annexin $V$ staining. In line with literature $[9,18]$, we observed an increased prevalence of Annexin V-positive cells upon treatment with $1.5 \mathrm{mM} \mathrm{Cu}$, indicating $\mathrm{Cu}$-induced apoptosis (Fig. 4 b). In addition, while treatment with 100 $\mu \mathrm{M}$ Losartan decreased Cu-induced apoptosis (Fig. 4 b), 25 $\mu \mathrm{M}$ Candesartan Cilexetil did not (data not shown). Taken together, these data indicate that specific ARBs can prevent $\mathrm{Cu}$-induced cell death and apoptosis in human cells.

\section{DISCUSSION}

In the present study we report on the screening of the Pharmakon 1600 repositioning library in order to identify agents that increase tolerance to $\mathrm{Cu}$-induced toxicity in yeast and the identification of the drug class of ARBs. Next, we showed that specific ARBs increase yeast tolerance to $\mathrm{Cu}$ and $\mathrm{Cp}$, and affect markers of $\mathrm{Cu}$-induced apoptosis. Likewise, we found that specific ARBs increase human cell line tolerance to $\mathrm{Cu}$ and decrease the prevalence of apoptotic markers.

Our Cu-based yeast toxicity screen resulted in the identification of 7 clinically used drugs that can significantly increase yeast tolerance to $\mathrm{Cu}$ (data not shown) including the ARBs Candesartan and Losartan that are used as antihypertensive drugs [63]. The drug class of ARBs is of particular interest given the numerous reports that describe beneficial effects of ARBs in human pathologies related to mitochondrial dysfunction. For instance Losartan treatment reduces mitochondrial dysfunction in aged and spon- a

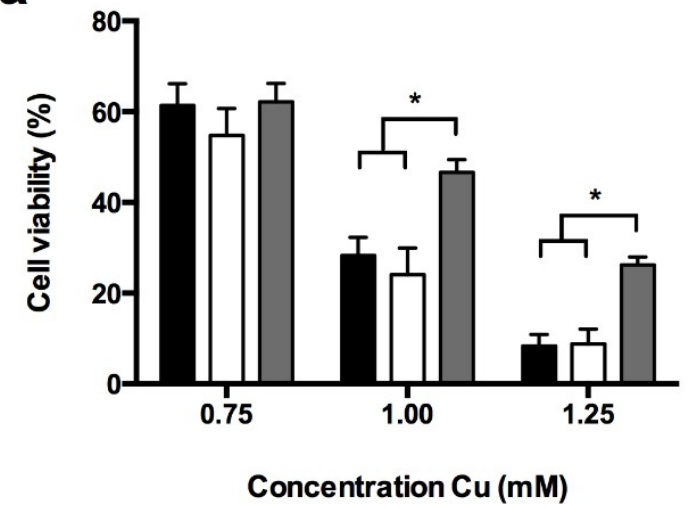

b

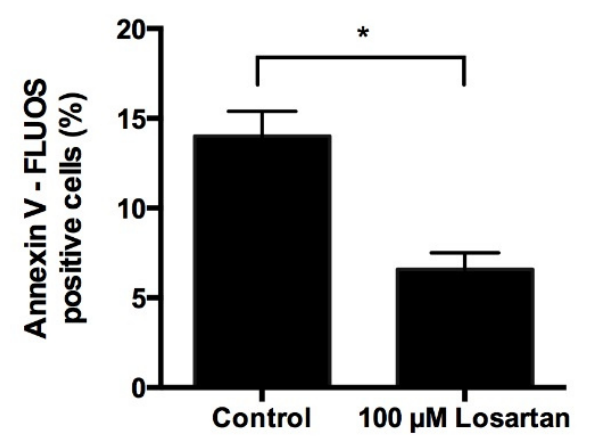

FIGURE 4: Losartan prevents $\mathrm{Cu}$-induced apoptosis in HepG2 cells. (a) Losartan increases HepG2 cell viability in presence of Cu. HepG2 cells were treated with $\mathrm{Cu}(0.75$ $\mathrm{mM}-1.25 \mathrm{mM})$ in presence of control (1\% DMSO, black bars), 25 $\mu \mathrm{M}$ Candesartan Cilexetil (white bars) or 100 $\mu \mathrm{M}$ Losartan (grey bars). Following $48 \mathrm{~h}$ of incubation, cell viability was determined by

MTT viability staining, and expressed as compared to cells receiving no Cu. Biological repeat is four. (***P < 0.001; ANOVA test using Tukey correction). (b) Losartan prevents Cu-induced apoptosis in HepG2 cells. HepG2 cells were treated for $1.5 \mathrm{mM}$ Cu in absence (control) or presence of $100 \mu \mathrm{M}$ Losartan for $24 \mathrm{~h}$. Subsequently, cells were stained with FLUOS-labeled Annexin V and samples were analyzed by flow cytometry. Biological repeats is three. (**P $<0.01$; Student t-test). 
taneously hypertensive rats $[35,36]$. Furthermore, in a comparative study, Losartan, Olmesartan and Valsartan were shown to prevent liver fibrosis in alloxan-induced diabetic rats. In contrast to Losartan and Valsartan treatment, Olmesartan treatment preserves mitochondrial ultrastructure [39]. Even protective effects of ARBs against Alzheimer disease have been suggested $[40,41]$ and long term Losartan administration to rats significantly increases life span [42]. Recently, Olmesartan treatment was shown to attenuate high fat diet-induced decreased mitochondrial respiration [64], while Losartan was reported to ameliorate mitochondrial function in indirect flight muscles in Drosophila melanogaster [65]. An additional advantage of ARBs is that they are well tolerated and not associated with class-related side effects $[66,67]$. In all these studies, however, the underlying molecular mechanism of these beneficial effects of ARBs on mitochondrial function and tolerance to apoptosis were not addressed.

While some ARBs are specific to either $\mathrm{Cu}$ or $\mathrm{Cp}$ induced toxicity (Valsartan or Candesartan and Irbesartan, respectively), other ARBs do not show any effect to either toxic insult. However, the ARBs Candesartan Cilexetil, Losartan and Olmesartan Medoxomil display activity against both $\mathrm{Cu}$ and $\mathrm{Cp}$ (Table 1). Interestingly, Candesartan Cilexetil and Olmesartan Medoxomil are ester prodrug versions of their parent compound Candesartan and Olmesartan, respectively, and display improved bioavailability $[68,69]$. It is therefore plausible that the uptake of these prodrugs in yeast is more efficient, and thereby is a determinant of their protective effect against $\mathrm{Cu}$ and $\mathrm{Cp}$. Nonetheless, given the effect of these aforementioned ARBs against both toxic agents, this suggests that $\mathrm{Cu}$ and $\mathrm{Cp}$ toxicity in yeast may be mediated by overlapping pathways. Common defense mechanisms against $\mathrm{Cu}$ and $\mathrm{Cp}$ have been described in yeast and mammalian cells. For example, pre-treatment of yeast cells with $\mathrm{Cu}$ or $\mathrm{Cp}$ is reported to increase yeast tolerance to $\mathrm{Cp}$ or $\mathrm{Cu}$, respectively, in both cases due to degradation and delocalization of the $\mathrm{Cu}$ transporter Ctr1p [70]. Additionally, at low $\mathrm{Cu}$ concentrations that do not affect $\mathrm{Ctr} 1 \mathrm{p}, \mathrm{Cu}$ also protects against $\mathrm{Cp}$-induced toxicity in yeast [71]. In mammalian cells, $\mathrm{Cu}$ and $\mathrm{Cp}$ increase activity of aSMase, leading to an increased production of the apoptosis inducer ceramide [9, 72, 73] and both $\mathrm{Cu}$ and $\mathrm{Cp}$-induced toxicity have also been associated with pro-apoptotic Bax [74-80]. As we observed that ARBs cannot rescue yeast growth defects induced by noxious insults such as tunicamycin, valproic acid, acetic acid or CCCP, it seems that the protective effect of ARBs is toxin-specific.

A Cu-chelating activity has never been reported for ARBs. However, Losartan has been described to spontaneously form an insoluble complex with $\mathrm{Cu}$ [81], and ARB-Cu complexes have been reported to display anti-oxidant activity [82-84], pointing to the possibility of Cu-chelation by ARBs. Whether the underlying mechanistic event that governs the ARB-mediated protection against $\mathrm{Cu}$-induced toxicity is attributed to Cu complexation by ARBs has yet to be investigated. As Cu-complexation does not explain the
ARBs' effect in Cp toxicity, it is conceivable that ARBs increase yeast tolerance to $\mathrm{Cu}$ and $\mathrm{Cp}$ in other ways.

With respect to $C p$ toxicity, there are some in vivo reports that describe the effect of ARBs against $\mathrm{Cp}$-induced toxicity. For instance, chronic Losartan treatment in rats after $\mathrm{Cp}$ administration improves weight gain following $\mathrm{Cp}$ induced reduced food intake and weight loss [85]. Losartan also reduces $\mathrm{Cp}$-induced lipid peroxidation and glutathione depletion in rat kidneys [86]. In addition, combination therapies with Losartan and Vitamin E [87] or C [88] as treatment for $\mathrm{Cp}$-induced nephrotoxicity in rats have been tested, but without any significant result. Noteworthy is that both Candesartan and a combination of Candesartan and $\mathrm{Cp}$ have been shown to suppress tumor growth in a xenograft model for bladder cancer in mice. However, the combination of Candesartan and $\mathrm{Cp}$ proved to be less effective than Candesartan alone, suggesting a protective effect of Candesartan against $\mathrm{Cp}$-induced apoptosis [89].

Yeast is a powerful model organism to study various cellular processes, including mitochondrial function and apoptosis due to conservation of their regulatory pathways [90-93]. Apart from antifungal drug discovery purposes [28, 94], yeast-based screens are often used to identify compounds that can affect disease-relevant targets, such as for instance calcineurin [95], human telomerase [96], or synergetic DNA-damaging drug combinations [97]. Also, yeast assays have been reportedly used to gain insight into the mode of action of clinically used compounds [98]. For instance, the anti-anginal drug Molsidomine [99] was shown to target lanosterol synthase in the sterol biosynthetic pathway [98].

The results of this study indicate that $\mathrm{Cu}$-induced apoptosis in yeast is independent of Aif1p, Nuc1p or Yca1p. In addition, the data presented here also highlight the fact that despite the conservation of several important metabolic pathways, there still remain yeast and mammalian cell-specific aspects: while in mammalian cells Cu-induced toxicity is directly related to impact on mitochondrial function [4-8], there are contradictory reports regarding $\mathrm{Cu}$ induced toxicity and mitochondrial function in yeast [1517]. Indeed, the loss of the cytoplasmic ROS generator Yno1p or cytoplasmic Sod1p increases or decreases yeast tolerance to $\mathrm{Cu}$, respectively, indicating that $\mathrm{Cu}$-induced toxicity in yeast seems associated with detrimental cytoplasmic, but does not exclude, mitochondrial ROS production. Still, by using $\mathrm{Cu}$-induced toxicity in yeast as a screening model, we were able to identify the plant-derived peptide OSIP108 as an agent that prevents $\mathrm{Cu}$-induced apoptosis in yeast and human cells, preserves mitochondrial ultrastructure in human cells, but also prevents $\mathrm{Cu}$-induced liver damage and decreases oxidative stress levels in zebrafish larvae $[18,23,24]$. Hence, these reports illustrate the validity of our screen to identify agents with a putative application in persevering mitochondrial function and preventing apoptosis. This is of particular importance as mitochondrial dysfunction, ROS and apoptosis have been linked to several human conditions such as aging, cancer [100], diabetes $[101,102]$ and non-alcoholic steatohepatitis [103], but also neurodegenerative disorders [104] including Alzheimer 
disease [105] and Parkinson's disease [106, 107], and rare diseases such as WD [4]. Current treatment options for mitochondrial dysfunction-related disorders are inadequate and mostly consist of the administration of cofactors and oxygen radical scavengers [108-110]. Thus, there still is an urgent need for novel treatments in combating mitochondrial dysfunction-related disorders and ARBs may show promise, as well as OSIP108, in this regard.

Noteworthy is that while the effects of ARBs on cellular metabolism in a higher eukaryotic setting is typically based on its ability to block the interaction between Angiotensin II and the Angiotensin II Receptor Type 1, neither the ligand nor the receptor have thus far been identified in $S$. cerevisiae, suggesting the existence of additional cellular targets for ARBs $[44,63]$. Thus, it is plausible that ARBs mediate Cu-tolerance in yeast and mammalian cells irrespective of their known cellular targets. Hence, despite that our yeast data show promise regarding the protective effect of ARBs against $\mathrm{Cu}$-induced toxicity, it therefore remains to be investigated whether their mode of action in yeast can be translated to a mammalian setting.

In conclusion, this study again highlights the potential of $S$. cerevisiae as a model organism, to identify novel compounds that increase tolerance to inducers of mitochondrial dysfunction in mammalian cells such as $\mathrm{Cu}$. Unraveling the anti-Cu mode of action of ARBs in yeast might reveal new therapeutic targets in treatment of $W D$, or mitochondrial dysfunction-related conditions in general.

\section{MATERIALS AND METHODS}

\section{Materials and microorganisms}

The yeast strains used in this study is Saccharomyces cerevisiae wild type yeast strain BY4741 (WT) and corresponding mutants ( $\Delta$ aif1, $\Delta c r s 5, \Delta c t a 1, \Delta c t t 1, \Delta c u p 2, \Delta g r x 5, \Delta$ nuc1, $\Delta$ sod1, $\Delta$ sod2, $\Delta y c a 1, \Delta y n o 1)$ (Euroscarf, Germany) were cultured in $\mathrm{SC}(0.77 \mathrm{~g} / \mathrm{L}$ complete amino acid supplement mixture (CSM) (Bio 101 Systems); $6.7 \mathrm{~g} / \mathrm{L}$ yeast nitrogen base without amino acids (YNB); $20 \mathrm{~g} / \mathrm{L}$ glucose). HepG2 cells, human hepatoma cells, were purchased from ATCC (Rockville, MD, USA) and grown in Minimal Essential Medium (MEM) supplemented with $10 \%$ fetal calf serum, $2 \mathrm{mM} \mathrm{L-glutamine,} 100 \mathrm{U} / \mathrm{ml}$ penicillin and $100 \mu \mathrm{g} / \mathrm{ml}$ streptomycin. Cisdiamminedichloroplatinum (II) (cisplatin, $\mathrm{Cp}$ ), copper sulphate pentahydrate and copper chloride $\left(\mathrm{CuCl}_{2}, \mathrm{Cu}\right)$ were purchased from Sigma-Aldrich (St. Louis, MO, USA) and dissolved in DMSO and distilled $\mathrm{H}_{2} \mathrm{O}$ respectively. Note that there is some controversy in literature regarding the use of DMSO as solvent for $\mathrm{Cp}$. We however did not observe major differences in $\mathrm{Cp}$ induced toxicity in yeast upon using either DMSO or $0.9 \% \mathrm{NaCl}$ in distilled $\mathrm{H}_{2} \mathrm{O}$ as solvent for $\mathrm{Cp}$. The Pharmakon 1600 repositioning library (10 mM in DMSO) was obtained from MicroSource Discovery Systems, Gaylordsville, CT, USA. All Angiotensin II Type 1 receptor blockers (ARBs) (Candesartan, Candesartan Cilexetil, Eprosartan, Irbesartan, Losartan, Olmesartan, Olmesartan Medoxomil, Telmisartan, Trityl Candesartan Cilexetil and Valsartan, as listed in Table 1) were purchased from Sequoia Research Products (Pangbourne, UK) and dissolved in DMSO. Protocols involving the effect of ARBs on yeast growth in presence of valproic acid, tunicamycin, acetic acid or CCCP are included in the supplementary data.

\section{Yeast $\mathrm{Cu}$ toxicity screen in solid media}

The Pharmakon 1600 repositioning library was screened using a Cu-induced toxicity yeast model as described [18].

\section{Yeast survival in presence of $\mathrm{Cu}$ and $\mathrm{Cp}$ in liquid media}

A WT overnight culture (ONC) in SC was diluted to $\mathrm{OD}_{600}=2$ in fresh SC and incubated with $2 \%$ DMSO (vehicle control) or ARB $(25 \mu \mathrm{M}-100 \mu \mathrm{M})$ in presence or absence of $2 \mathrm{mM} \mathrm{CuSO}_{4}$ or $250 \mu \mathrm{M} \mathrm{Cp}$ for $4 \mathrm{~h}$ or $16 \mathrm{~h}$, respectively. Following incubation at $30^{\circ} \mathrm{C}$ and $250 \mathrm{rpm}$, proper cell dilutions were plated onto YPD agar plates (1\% Yeast extract, $2 \%$ Bacteriological peptone, $2 \%$ glucose and $1.5 \%$ agar) and survival was calculated as compared to an unstressed yeast culture. Regarding the effect of dhSph or OSIP108 on yeast tolerance to Cu upon treatment with Candesartan Cilexetil, cells were treated as described above in absence (2\% DMSO) or presence of OSIP108 (12.5 $\mu \mathrm{M}$ or $25 \mu \mathrm{M})$ and $100 \mu \mathrm{M}$ Candesartan Cilexetil.

\section{Detection of apoptotic markers in yeast}

To determine $\mathrm{Cu}$-induced ROS production Cu-treated yeast cells were stained with $5 \mu \mathrm{g} / \mathrm{ml}$ dihydroethidium (Molecular Probes) (DHE) and analyzed by flow cytometry as described [18]. Subsequent data analysis was performed by using FlowJo software (Tree Star Inc., Ashland, MA, USA). For detection of DNA fragmentation, yeast cells were stained by Terminal deoxynucleotidyl transferase dUTP nick end labeling (TUNEL) assay as described [18]. TUNEL positive cells were imaged by fluorescence microscopy (Zeiss Axio Imager Z1 fluorescence microscope) and at least 600 cells/samples were manually counted.

\section{Yeast spot plating}

Overnight yeast cultures in $\mathrm{SC}$ were diluted to $\mathrm{OD}_{600}=0.01$ and 5 fold-serial dilutions were spotted on control plates $(0$ $\left.\mathrm{mM} \mathrm{CuSO}{ }_{4}\right)$ or Cu-containing (1.25 mM - $\left.1.5 \mathrm{mM}\right)$ solid SC medium (1.5\% agar) in presence of $0.5 \%$ DMSO (control) or $100 \mu \mathrm{M}$ Candesartan Cilexetil. Subsequently, plates were incubated at $30^{\circ} \mathrm{C}$ for $48 \mathrm{~h}$.

\section{HepG2 Cu toxicity experiments}

HepG2 viability upon treatment with $\mathrm{CuCl}_{2}(0.75 \mathrm{mM}-1.25$ $\mathrm{mM}$ ) in presence of $1 \%$ DMSO (control), $25 \mu \mathrm{M}$ Candesartan Cilexetil or $100 \mu \mathrm{M}$ Losartan was performed as described previously [21]. Briefly, $10^{4}$ cells were seeded in triplicates in 96 well plates and incubated for $24 \mathrm{~h}$. Next day, cells were treated with copper and/or Candesartan Cilexetil or Losartan and further incubated for $48 \mathrm{~h}$. Cell viability was determined by MTT assay and results were calculated as percentage of untreated control cells.

\section{Detection of apoptosis and oxidative stress in HepG2 cells} Detection of apoptotic markers by FLUOS-Annexin V (Roche Diagnostics NV Belgium, Belgium) staining and subsequent flow cytometry analysis in HepG2 cells upon treatment with $1.5 \mathrm{mM} \mathrm{CuCl}_{2}$ in presence of $1 \%$ DMSO (control) or $100 \mu \mathrm{M}$ Losartan was performed as described previously [21]. Briefly, $10^{6}$ cells were seeded in a 6 well plate and incubated for $24 \mathrm{~h}$. Next day, cells were treated with copper and control or Losartan Cilexetil and Losartan for an additional $24 \mathrm{~h}$. Cell culture supernatants and cells were collected and subjected to FLUOSAnnexin $\mathrm{V}$ staining followed by flow cytometry analysis (Beckman Coulter, Germany). 


\section{ACKNOWLEDGEMENTS}

This work was supported by grants from FWO-Vlaanderen (G.A062.10N and G.0414.09) and 'Bijzonder Onderzoeksfonds KU Leuven' (GOA/2008/11). P.S. is supported through a PhDgrant by IWT-Vlaanderen; G.C by FP7-PEOPLE (grant 247506); D.C. by FWO-Vlaanderen as a fundamental-clinical researcher; and K.T. by 'Industrial Research Fund' of KU Leuven (IOF-M). The authors acknowledge Geert Schoofs (CMPG, KU Leuven, Belgium) for flow cytometry analysis.

\section{SUPPLEMENTAL MATERIAL}

All supplemental data for this article are available online at www.microbialcell.com.

\section{CONFLICT OF INTEREST}

The authors declare no conflict of interest.

\section{REFERENCES}

1. Loudianos G, Gitlin JD (2000). Wilson's disease. Seminars in liver disease 20(3): 353-364.

2. Huster D (2010). Wilson disease. Best practice \& research Clinical gastroenterology 24(5): 531-539.

3. Ala A, Walker AP, Ashkan K, Dooley JS, Schilsky ML (2007). Wilson's disease. Lancet 369(9559): 397-408.

4. Zischka H, Lichtmannegger J (2014). Pathological mitochondrial copper overload in livers of Wilson's disease patients and related animal models. Annals of the New York Academy of Sciences.

5. Seth R, Yang S, Choi S, Sabean M, Roberts EA (2004). In vitro assessment of copper-induced toxicity in the human hepatoma line, Hep G2. Toxicology in vitro : an international journal published in association with BIBRA 18(4): 501-509.

6. Sokol RJ, Twedt D, McKim JM, Jr., Devereaux MW, Karrer FM, Kam I, von Steigman G, Narkewicz MR, Bacon BR, Britton RS, et al. (1994). Oxidant injury to hepatic mitochondria in patients with Wilson's disease and Bedlington terriers with copper toxicosis. Gastroenterology 107(6): 1788-1798.

7. Zischka H, Lichtmannegger J, Schmitt S, Jagemann N, Schulz S, Wartini D, Jennen L, Rust C, Larochette N, Galluzzi L, Chajes V, Bandow N, Gilles VS, DiSpirito AA, Esposito I, Goettlicher M, Summer KH, Kroemer $G$ (2011). Liver mitochondrial membrane crosslinking and destruction in a rat model of Wilson disease. The Journal of clinical investigation 121(4): 1508-1518.

8. Roberts $\mathrm{EA}$, Robinson $\mathrm{BH}$, Yang $\mathrm{S}$ (2008). Mitochondrial structure and function in the untreated Jackson toxic milk (tx-j) mouse, a model for Wilson disease. Molecular genetics and metabolism 93(1): 54-65.

9. Lang PA, Schenck M, Nicolay JP, Becker JU, Kempe DS, Lupescu A, Koka S, Eisele K, Klarl BA, Rubben H, Schmid KW, Mann K, Hildenbrand $\mathrm{S}$, Hefter $\mathrm{H}$, Huber SM, Wieder T, Erhardt A, Haussinger D, Gulbins E, Lang $F$ (2007). Liver cell death and anemia in Wilson disease involve acid sphingomyelinase and ceramide. Nature medicine 13(2): 164170

10. Pettus BJ, Chalfant CE, Hannun YA (2002). Ceramide in apoptosis: an overview and current perspectives. Biochimica et biophysica acta 1585(2-3): 114-125.

11. Kruidering M, Van de Water B, de Heer E, Mulder GJ, Nagelkerke JF (1997). Cisplatin-induced nephrotoxicity in porcine proximal tubular cells: mitochondrial dysfunction by inhibition of complexes I to IV of the respiratory chain. The Journal of pharmacology and experimental therapeutics 280(2): 638-649.

\section{COPYRIGHT}

(C) 2014 Spincemaille et al. This is an open-access article released under the terms of the Creative Commons Attribution (CC BY) license, which allows the unrestricted use, distribution, and reproduction in any medium, provided the original author and source are acknowledged.

Please cite this article as: Pieter Spincemaille, Gursimran Chandhok, Andree Zibert, Hartmut Schmidt, Jef Verbeek, Patrick Chaltin, Bruno P.A. Cammue, David Cassiman, Karin Thevissen (2014). Angiotensin II type 1 receptor blockers increase tolerance of cells to copper and cisplatin. Microbial Cell 1(11): 352-364. doi: 10.15698/mic2014.11.175

12. Santandreu FM, Roca P, Oliver J (2010). Uncoupling protein-2 knockdown mediates the cytotoxic effects of cisplatin. Free radical biology \& medicine 49(4): 658-666.

13. Marullo R, Werner E, Degtyareva N, Moore B, Altavilla G, Ramalingam SS, Doetsch PW (2013). Cisplatin Induces a Mitochondrial-ROS Response That Contributes to Cytotoxicity Depending on Mitochondrial Redox Status and Bioenergetic Functions. PloS one 8(11): e81162.

14. Mukhopadhyay P, Horvath B, Zsengeller Z, Zielonka J, Tanchian G, Holovac E, Kechrid M, Patel V, Stillman IE, Parikh SM, Joseph J, Kalyanaraman B, Pacher P (2012). Mitochondrial-targeted antioxidants represent a promising approach for prevention of cisplatin-induced nephropathy. Free radical biology \& medicine 52(2): 497-506.

15. Banci L, Bertini I, Ciofi-Baffoni S, D'Alessandro A, Jaiswal D, Marzano V, Neri S, Ronci M, Urbani A (2011). Copper exposure effects on yeast mitochondrial proteome. Journal of proteomics $74(11)$ : 2522-2535.

16. Keyhani E (1987). Morphological basis for multiple interactions of ethidium bromide (EB) with yeast Candida utilis. Cell biology international reports 11(6): 439-447.

17. Cobine PA, Ojeda LD, Rigby KM, Winge DR (2004). Yeast contain a non-proteinaceous pool of copper in the mitochondrial matrix. The Journal of biological chemistry 279(14): 14447-14455.

18. Spincemaille $P$, Chandhok G, Newcomb B, Verbeek J, Vriens K, Zibert A, Schmidt H, Hannun YA, van Pelt J, Cassiman D, Cammue BP, Thevissen $\mathrm{K}$ (2014). The plant decapeptide OSIP108 prevents copperinduced apoptosis in yeast and human cells. Biochimica et biophysica acta 1843(6): 1207-1215.

19. Rego A, Trindade D, Chaves SR, Manon S, Costa V, Sousa MJ, Corte-Real M (2013). The yeast model system as a tool towards the understanding of apoptosis regulation by sphingolipids. FEMS yeast research.

20. Spincemaille $P$, Cammue BPA, Thevissen $K$ (2014). Sphingolipids and Mitochondrial Function, Lessons Learned from Yeast. Microbial Cell 1(7): 210-224.

21. Spincemaille $P$, Matmati $N$, Hannun $Y A$, Cammue BP, Thevissen $K$ (2014). Sphingolipids and mitochondrial function in budding yeast. Biochimica et biophysica acta 1840(10): 3131-3137. 
22. Lee YJ, Huang X, Kropat J, Henras A, Merchant SS, Dickson RC, Chanfreau GF (2012). Sphingolipid signaling mediates iron toxicity. Cell metabolism 16(1): 90-96.

23. De Coninck B, Carron D, Tavormina P, Willem L, Craik DJ, Vos C, Thevissen K, Mathys J, Cammue BP (2013). Mining the genome of Arabidopsis thaliana as a basis for the identification of novel bioactive peptides involved in oxidative stress tolerance. Journal of experimental botany 64(17): 5297-5307.

24. Spincemaille $P$, Pham DH, Chandhok $G$, Verbeek J, Zibert $A$, Libbrecht L, Schmidt H, Esguerra CV, de Witte PA, Cammue BP, Cassiman D, Thevissen K (2014). The plant decapeptide OSIP108 prevents copper-induced toxicity in various models for Wilson disease. Toxicology and applied pharmacology.

25. Ashburn TT, Thor KB (2004). Drug repositioning: identifying and developing new uses for existing drugs. Nature reviews Drug discovery 3(8): 673-683.

26. Tobinick EL (2009). The value of drug repositioning in the current pharmaceutical market. Drug news \& perspectives 22(2): 119-125.

27. Chopra S, Torres-Ortiz M, Hokama L, Madrid P, Tanga M, Mortelmans K, Kodukula K, Galande AK (2010). Repurposing FDAapproved drugs to combat drug-resistant Acinetobacter baumannii. The Journal of antimicrobial chemotherapy 65(12): 2598-2601.

28. Delattin N, De Brucker K, Vandamme K, Meert E, Marchand A, Chaltin P, Cammue BP, Thevissen K (2014). Repurposing as a means to increase the activity of amphotericin $B$ and caspofungin against Candida albicans biofilms. The Journal of antimicrobial chemotherapy 69(4): 1035-1044.

29. Sardana D, Zhu C, Zhang M, Gudivada RC, Yang L, Jegga AG (2011). Drug repositioning for orphan diseases. Briefings in bioinformatics 12(4): 346-356.

30. Dameron CT, Harrison MD (1998). Mechanisms for protection against copper toxicity. The American journal of clinical nutrition 67(5 Suppl): 1091S-1097S.

31. Sutherland DE, Stillman MJ (2011). The "magic numbers" of metallothionein. Metallomics : integrated biometal science 3(5): 444463.

32. Franchini M, Veneri D (2004). Iron-chelation therapy: an update. The hematology journal : the official journal of the European Haematology Association / EHA 5(4): 287-292.

33. Andersen A (2006). Final amended report on the safety assessment of oxyquinoline and oxyquinoline sulfate as used in cosmetics. International journal of toxicology 25 Suppl 1:1-9.

34. Naik P, Murumkar P, Giridhar R, Yadav MR (2010). Angiotensin II receptor type 1 (AT1) selective nonpeptidic antagonists--a perspective. Bioorganic \& medicinal chemistry 18(24): 8418-8456.

35. de Cavanagh EM, Piotrkowski B, Basso N, Stella I, Inserra F, Ferder L, Fraga CG (2003). Enalapril and losartan attenuate mitochondrial dysfunction in aged rats. FASEB journal : official publication of the Federation of American Societies for Experimental Biology 17(9): 1096-1098.

36. de Cavanagh EM, Toblli JE, Ferder L, Piotrkowski B, Stella I, Inserra $F$ (2006). Renal mitochondrial dysfunction in spontaneously hypertensive rats is attenuated by losartan but not by amlodipine. American journal of physiology Regulatory, integrative and comparative physiology 290(6): R1616-1625.

37. Li X, Yuan L, Li J, Li H, Cheng S (2012). Blockade of renin angiotensin system increased resistance to STZ-induced diabetes in rats with long-term high-fat diet. Experimental diabetes research 2012:618923.
38. Qiang G, Zhang L, Yang X, Xuan Q, Shi L, Zhang H, Chen B, Li X, Zu M, Zhou D, Guo J, Yang H, Du G (2012). Effect of valsartan on the pathological progression of hepatic fibrosis in rats with type 2 diabetes. European journal of pharmacology 685(1-3): 156-164.

39. Sipal S, Halici Z, Kiki I, Polat B, Albayrak A, Albayrak F, Karakus E, Aksak S, Ozturk B, Gundogdu C (2012). Comparative study of three angiotensin II type 1 receptor antagonists in preventing liver fibrosis in diabetic rats: stereology, histopathology, and electron microscopy. Journal of molecular histology 43(6): 723-735.

40. Kurinami $H$, Shimamura $M$, Sato $N$, Nakagami $H$, Morishita R (2013). Do angiotensin receptor blockers protect against Alzheimer's disease? Drugs \& aging 30(6): 367-372.

41. Gard PR (2004). Angiotensin as a target for the treatment of Alzheimer's disease, anxiety and depression. Expert opinion on therapeutic targets $8(1): 7-14$.

42. Basso N, Cini R, Pietrelli A, Ferder L, Terragno NA, Inserra F (2007). Protective effect of long-term angiotensin II inhibition. American journal of physiology Heart and circulatory physiology 293(3): H1351-1358.

43. Timmermans PB, Duncia JV, Carini DJ, Chiu AT, Wong PC, Wexler RR, Smith RD (1995). Discovery of losartan, the first angiotensin II receptor antagonist. Journal of human hypertension 9 Suppl 5:S3-18.

44. Michel MC, Foster C, Brunner HR, Liu L (2013). A systematic comparison of the properties of clinically used angiotensin II type 1 receptor antagonists. Pharmacological reviews 65(2): 809-848.

45. Liang Q, Zhou B (2007). Copper and manganese induce yeast apoptosis via different pathways. Molecular biology of the cell 18(12): 4741-4749.

46. Carmona-Gutierrez D, Eisenberg T, Buttner S, Meisinger C, Kroemer G, Madeo F (2010). Apoptosis in yeast: triggers, pathways, subroutines. Cell death and differentiation 17(5): 763-773.

47. Ferreira $P$, Cardoso $T$, Ferreira $F$, Fernandes-Ferreira $M$, Piper $P$, Sousa MJ (2014). Mentha piperita essential oil induces apoptosis in yeast associated with both cytosolic and mitochondrial ROS-mediated damage. FEMS yeast research.

48. Wissing $S$, Ludovico $P$, Herker E, Buttner S, Engelhardt SM, Decker T, Link A, Proksch A, Rodrigues F, Corte-Real M, Frohlich KU, Manns J, Cande C, Sigrist SJ, Kroemer G, Madeo F (2004). An AIF orthologue regulates apoptosis in yeast. The Journal of cell biology 166(7): 969974.

49. Buttner S, Eisenberg T, Carmona-Gutierrez D, Ruli D, Knauer $H$, Ruckenstuhl C, Sigrist C, Wissing S, Kollroser M, Frohlich KU, Sigrist S, Madeo $F$ (2007). Endonuclease $G$ regulates budding yeast life and death. Molecular cell 25(2): 233-246.

50. Guaragnella N, Pereira C, Sousa MJ, Antonacci L, Passarella S, Corte-Real M, Marra E, Giannattasio S (2006). YCA1 participates in the acetic acid induced yeast programmed cell death also in a manner unrelated to its caspase-like activity. FEBS letters 580(30): 6880-6884.

51. Madeo F, Herker E, Maldener C, Wissing S, Lachelt S, Herlan M, Fehr M, Lauber K, Sigrist SJ, Wesselborg S, Frohlich KU (2002). A caspase-related protease regulates apoptosis in yeast. Molecular cell 9(4): 911-917.

52. Horowitz A, Lapointe J, Eid R, Sheibani S, Gharib N, Jones NK, Vali $\mathrm{H}$, Mandato CA, Greenwood MT (2013). The human septin7 and the yeast CDC10 septin prevent Bax and copper mediated cell death in yeast. Biochimica et biophysica acta.

53. Cohen G, FessI F, Traczyk A, Rytka J, Ruis H (1985). Isolation of the catalase A gene of Saccharomyces cerevisiae by complementation of the cta1 mutation. Molecular \& general genetics : MGG 200(1): 7479. 
54. Petrova VY, Drescher D, Kujumdzieva AV, Schmitt MJ (2004). Dual targeting of yeast catalase $A$ to peroxisomes and mitochondria. The Biochemical journal 380(Pt 2): 393-400.

55. Bermingham-McDonogh O, Gralla EB, Valentine JS (1988). The copper, zinc-superoxide dismutase gene of Saccharomyces cerevisiae: cloning, sequencing, and biological activity. Proceedings of the National Academy of Sciences of the United States of America 85(13): 4789-4793.

56. Steinman HM (1980). The amino acid sequence of copper-zinc superoxide dismutase from bakers' yeast. The Journal of biological chemistry 255(14): 6758-6765.

57. Rodriguez-Manzaneque MT, Ros J, Cabiscol E, Sorribas A, Herrero E (1999). Grx5 glutaredoxin plays a central role in protection against protein oxidative damage in Saccharomyces cerevisiae. Molecular and cellular biology 19(12): 8180-8190.

58. Rinnerthaler M, Buttner S, Laun $P$, Heeren G, Felder TK, Klinger $H$, Weinberger M, Stolze K, Grousl T, Hasek J, Benada O, Frydlova I, Klocker A, Simon-Nobbe B, Jansko B, Breitenbach-Koller H, Eisenberg T, Gourlay CW, Madeo F, Burhans WC, Breitenbach M (2012). Yno1p/Aim14p, a NADPH-oxidase ortholog, controls extramitochondrial reactive oxygen species generation, apoptosis, and actin cable formation in yeast. Proceedings of the National Academy of Sciences of the United States of America 109(22): 8658-8663.

59. Culotta VC, Howard WR, Liu XF (1994). CRS5 encodes a metallothionein-like protein in Saccharomyces cerevisiae. The Journal of biological chemistry 269(41): 25295-25302.

60. Buchman C, Skroch P, Welch J, Fogel S, Karin M (1989). The CUP2 gene product, regulator of yeast metallothionein expression, is a copper-activated DNA-binding protein. Molecular and cellular biology 9(9): 4091-4095.

61. Welch J, Fogel S, Buchman C, Karin M (1989). The CUP2 gene product regulates the expression of the CUP1 gene, coding for yeast metallothionein. The EMBO journal 8(1): 255-260.

62. Sideri TC, Willetts SA, Avery SV (2009). Methionine sulphoxide reductases protect iron-sulphur clusters from oxidative inactivation in yeast. Microbiology 155(Pt 2): 612-623.

63. Catanzaro DF, Frishman WH (2010). Angiotensin receptor blockers for management of hypertension. Southern medical journal 103(7): 669-673.

64. Takada S, Kinugawa S, Hirabayashi K, Suga T, Yokota T, Takahashi M, Fukushima A, Homma T, Ono T, Sobirin MA, Masaki Y, Mizushima W, Kadoguchi T, Okita K, Tsutsui H (2013). Angiotensin II receptor blocker improves the lowered exercise capacity and impaired mitochondrial function of the skeletal muscle in type 2 diabetic mice. Journal of applied physiology 114(7): 844-857.

65. Momota R, Narasaki M, Komiyama T, Naito I, Ninomiya Y, Ohtsuka A (2013). Drosophila type XV/XVIII collagen mutants manifest integrin mediated mitochondrial dysfunction, which is improved by cyclosporin A and losartan. The international journal of biochemistry \& cell biology 45(5): 1003-1011.

66. Burnier M (2001). Angiotensin II type 1 receptor blockers. Circulation 103(6): 904-912.

67. Siragy HM (2011). A current evaluation of the safety of angiotensin receptor blockers and direct renin inhibitors. Vascular health and risk management 7:297-313.

68. Husain A, Azim SM, Mitra M, Bhasin P (2011). A Review on Candesartan: Pharmacological and Pharmaceutical Profile. Journal of Applied Pharmaceutical Science 01(10): 12-17.
69. Brunner HR (2002). The new oral angiotensin II antagonist olmesartan medoxomil: a concise overview. Journal of human hypertension 16 Suppl 2:S13-16.

70. Ishida S, Lee J, Thiele DJ, Herskowitz I (2002). Uptake of the anticancer drug cisplatin mediated by the copper transporter Ctr1 in yeast and mammals. Proceedings of the National Academy of Sciences of the United States of America 99(22): 14298-14302.

71. Ohashi K, Kajiya K, Inaba S, Hasegawa T, Seko Y, Furuchi T, Naganuma A (2003). Copper(II) protects yeast against the toxicity of cisplatin independently of the induction of metallothionein and the inhibition of platinum uptake. Biochemical and biophysical research communications 310(1): 148-152.

72. Rebillard A, Rioux-Leclercq N, Muller C, Bellaud $P$, Jouan F, Meurette O, Jouan E, Vernhet L, Le Quement C, Carpinteiro A, Schenck M, Lagadic-Gossmann D, Gulbins E, Dimanche-Boitrel MT (2008). Acid sphingomyelinase deficiency protects from cisplatin-induced gastrointestinal damage. Oncogene 27(51): 6590-6595.

73. Hou $Q$, Jin J, Zhou H, Novgorodov SA, Bielawska A, Szulc ZM, Hannun YA, Obeid LM, Hsu YT (2011). Mitochondrially targeted ceramides preferentially promote autophagy, retard cell growth, and induce apoptosis. Journal of lipid research 52(2): 278-288.

74. Li YW, Wang XH, Nin Q, Luo XP (2008). [Excessive copper induces hepatocyte apoptosis and affects $\mathrm{Bax}$ and $\mathrm{Bcl}-2$ expression in rat liver]. Chinese journal of contemporary pediatrics 10(1): 42-46.

75. Lee RH, Song JM, Park MY, Kang SK, Kim YK, Jung JS (2001). Cisplatin-induced apoptosis by translocation of endogenous Bax in mouse collecting duct cells. Biochemical pharmacology 62(8): 10131023.

76. Zhai Q, Ji H, Zheng Z, Yu X, Sun L, Liu X (2000). Copper induces apoptosis in BA/F3beta cells: Bax, reactive oxygen species, and NFkappaB are involved. Journal of cellular physiology 184(2): 161170.

77. Mitra S, Keswani T, Dey M, Bhattacharya S, Sarkar S, Goswami S, Ghosh N, Dutta A, Bhattacharyya A (2012). Copper-induced immunotoxicity involves cell cycle arrest and cell death in the spleen and thymus. Toxicology 293(1-3): 78-88.

78. Bolea R, Hortells P, Martin-Burriel I, Vargas A, Ryffel B, Monzon M, Badiola JJ (2010). Consequences of dietary manganese and copper imbalance on neuronal apoptosis in a murine model of scrapie. Neuropathology and applied neurobiology 36(4): 300-311.

79. McDonald ES, Windebank AJ (2002). Cisplatin-induced apoptosis of DRG neurons involves bax redistribution and cytochrome c release but not fas receptor signaling. Neurobiology of disease 9(2): 220-233.

80. Wei Q, Dong G, Franklin J, Dong Z (2007). The pathological role of Bax in cisplatin nephrotoxicity. Kidney international 72(1): 53-62.

81. Denadai AM, Da Silva JG, Guimaraes PP, Gomes LB, Mangrich AS, de Rezende EI, Daniel IM, Beraldo H, Sinisterra RD (2013). Control of size in losartan/copper(II) coordination complex hydrophobic precipitate. Materials science \& engineering C, Materials for biological applications 33(7): 3916-3922.

82. Etcheverry SB, Di Virgilio AL, Nascimento OR, Williams PA (2012). Dinuclear copper(II) complexes with valsartan. Synthesis, characterization and cytotoxicity. Journal of inorganic biochemistry 107(1): 25-33.

83. Etcheverry SB, Ferrer EG, Naso L, Barrio DA, Lezama L, Rojo T, Williams PA (2007). Losartan and its interaction with copper(II): biological effects. Bioorganic \& medicinal chemistry 15(19): 64186424. 
84. Islas MS, Rojo T, Lezama L, Merino MG, Cortes MA, Puyol MR, Ferrer EG, Williams PA (2013). Improvement of the antihypertensive capacity of candesartan and trityl candesartan by their SOD mimetic copper(II) complexes. Journal of inorganic biochemistry 123:23-33.

85. Deegan PM, Nolan C, Ryan MP, Basinger MA, Jones MM, Hande KR (1995). The role of the renin-angiotensin system in cisplatin nephrotoxicity. Renal failure 17(6): 665-674.

86. Saleh S, Ain-Shoka AA, El-Demerdash E, Khalef MM (2009). Protective effects of the angiotensin II receptor blocker losartan on cisplatin-induced kidney injury. Chemotherapy 55(6): 399-406.

87. Nematbakhsh M, Ashrafi F, Safari T, Talebi A, Nasri H, Mortazavi M, Khazaei M, Baradaran-Mahdavi MM (2012). Administration of vitamin $E$ and losartan as prophylaxes in cisplatin-induced nephrotoxicity model in rats. Journal of nephrology 25(3): 410-417.

88. Ashrafi F, Nematbakhsh M, Safari T, Talebi A, Nasri H, Khazaei M, Baradaran-Mahdavi MM, Jafapisheh A, Olia B, Pirhaji O, Hashemi-Nia SJ, Eshraghi F, Pezeshki Z, Mortazavi M (2012). A combination of vitamin $C$ and losartan for cisplatin-induced nephrotoxicity in rats. Iranian journal of kidney diseases 6(5): 361-365.

89. Kosugi M, Miyajima A, Kikuchi E, Kosaka T, Horiguchi Y, Murai M, Oya M (2009). Angiotensin II type 1 receptor antagonist enhances cisdichlorodiammineplatinum-induced cytotoxicity in mouse xenograft model of bladder cancer. Urology 73(3): 655-660.

90. Rea SL, Graham BH, Nakamaru-Ogiso E, Kar A, Falk MJ (2010). Bacteria, yeast, worms, and flies: exploiting simple model organisms to investigate human mitochondrial diseases. Developmental disabilities research reviews 16(2): 200-218.

91. Barrientos A (2003). Yeast models of human mitochondrial diseases. IUBMB life 55(2): 83-95.

92. Foury F, Kucej M (2002). Yeast mitochondrial biogenesis: a model system for humans? Current opinion in chemical biology 6(1): 106111

93. Frohlich KU, Fussi H, Ruckenstuhl C (2007). Yeast apoptosis--from genes to pathways. Seminars in cancer biology 17(2): 112-121.

94. Tebbets B, Stewart D, Lawry S, Nett J, Nantel A, Andes D, Klein BS (2012). Identification and characterization of antifungal compounds using a Saccharomyces cerevisiae reporter bioassay. PloS one 7(5): e36021.

95. Prescott TA, Panaretou B, Veitch NC, Simmonds MS (2014). A yeast chemical genetics approach identifies the compound 3,4,5trimethoxybenzyl isothiocyanate as a calcineurin inhibitor. FEBS letters 588(3): 455-458.

96. Wong LH, Unciti-Broceta A, Spitzer $M$, White $R$, Tyers $M$, Harrington $L$ (2013). A yeast chemical genetic screen identifies inhibitors of human telomerase. Chemistry \& biology 20(3): 333-340.

97. Torres NP, Lee AY, Giaever G, Nislow C, Brown GW (2013). A highthroughput yeast assay identifies synergistic drug combinations. Assay and drug development technologies 11(5): 299-307.
98. Lum PY, Armour CD, Stepaniants SB, Cavet G, Wolf MK, Butler JS, Hinshaw JC, Garnier P, Prestwich GD, Leonardson A, Garrett-Engele P, Rush CM, Bard M, Schimmack G, Phillips JW, Roberts CJ, Shoemaker DD (2004). Discovering modes of action for therapeutic compounds using a genome-wide screen of yeast heterozygotes. Cell 116(1): 121137.

99. Balakumaran K, Hugenholtz PG, Tijssen JG, Chadha DR (1983). Molsidomine, an effective long-acting anti-anginal drug. European heart journal 4(9): 655-661.

100. Singh KK (2004). Mitochondrial dysfunction is a common phenotype in aging and cancer. Annals of the New York Academy of Sciences 1019:260-264.

101. Yu L, Fink BD, Herlein JA, Sivitz WI (2013). Mitochondrial function in diabetes: novel methodology and new insight. Diabetes 62(6): 1833-1842.

102. Supale S, Li N, Brun T, Maechler P (2012). Mitochondrial dysfunction in pancreatic beta cells. Trends in endocrinology and metabolism: TEM 23(9): 477-487.

103. Verbeek J, Lannoo $M$, Pirinen $E$, Ryu $D$, Spincemaille $P$, van der Elst I, Windmolders $P$, Thevissen $K$, Cammue BPA, van Pelt J, Fransis $S$, Van Eyken P, Ceuterick-De Groote C, Van Veldhoven PP, Bedossa P, Nevens F, Auwerx J, Cassiman D (2014). Roux-en-y gastric bypass attenuates hepatic mitochondrial dysfunction in mice with nonalcoholic steatohepatitis. Gut In Press.

104. Federico A, Cardaioli E, Da Pozzo P, Formichi P, Gallus GN, Radi E (2012). Mitochondria, oxidative stress and neurodegeneration. Journal of the neurological sciences 322(1-2): 254-262.

105. Eckert A, Keil U, Marques CA, Bonert A, Frey C, Schussel K, Muller WE (2003). Mitochondrial dysfunction, apoptotic cell death, and Alzheimer's disease. Biochemical pharmacology 66(8): 1627-1634.

106. Venderova K, Park DS (2012). Programmed cell death in Parkinson's disease. Cold Spring Harbor perspectives in medicine 2(8).

107. Bueler H (2010). Mitochondrial dynamics, cell death and the pathogenesis of Parkinson's disease. Apoptosis : an international journal on programmed cell death 15(11): 1336-1353.

108. Dimauro S, Rustin P (2009). A critical approach to the therapy of mitochondrial respiratory chain and oxidative phosphorylation diseases. Biochimica et biophysica acta 1792(12): 1159-1167.

109. DiMauro S, Schon EA (2003). Mitochondrial respiratory-chain diseases. The New England journal of medicine 348(26): 2656-2668.

110. Scarpelli $M$, Cotelli MS, Mancuso $M$, Tomelleri $G$, Tonin $P$, Baronchelli C, Vielmi V, Gregorelli V, Todeschini A, Padovani A, Filosto $M$ (2010). Current options in the treatment of mitochondrial diseases. Recent patents on CNS drug discovery 5(3): 203-209. 